\title{
An evacuation building project for Cascadia earthquakes and tsunamis
}

\section{Un proyecto de edificio de evacuación para los terremotos y tsunamis Cascadia}

Fecha de entrega: 16 de marzo 2011

Fecha de aceptación: 10 de mayo 2011

\section{Jay Raskin ${ }^{1}$, Yumei Wang 2 , Marcella Boyer ${ }^{3}$, Tim Fiez ${ }^{4}$ Javier Moncada ${ }^{5}$, Kent $\mathrm{Yu}^{6}$ and Harry $\mathrm{Yeh}^{7}$}

\footnotetext{
${ }^{1}$ Ecola Architects, PC, P.O. Box 1160, 368 Elk Creek Road, Suite 409, Cannon Beach, Oregon 97110, USA, jay@ecolaarchitects.com

${ }^{2}$ Oregon Department of Geology and Mineral Industries (DOGAMI), 800 NE Oregon St., \#28 Suite 965, Portland, OR 97232, USA, yumei.wang@dogami.state.or.us

${ }^{3}$ Chinook GeoServices, Inc., 1508 Broadway Street, Vancouver, Washington 98663, USA, Marcy@Chinookgeoservices.com

${ }^{4}$ The Gartrell Group, 107 SE Washington St. Suite 453, Portland, OR 97214, USA, tim@gartrellgroup.com

${ }^{5}$ BERGER/ABAM Engineers Inc., 700 NE Multnomah Street, Suite 900, Portland, OR 97232-4189, USA, javier.moncada@abam.com

${ }^{6}$ Degenkolb Engineers, 707 SW Washington St., Suite 600, Portland, OR 97205, USA, KYu@degenkolb.com

${ }^{7}$ Coastal and Ocean Engineering, School of Civil \& Construction Engineering, Oregon State University, Corvallis, OR 97331-3212, USA, harry@engr.orst.edu
}

This paper discusses the need for a tsunami evacuation building (TEB) as a new risk management approach to Cascadia earthquakes and tsunamis. Taking its starting point from FEMA P646 (2008) guidelines for design of structures for evacuation from tsunamis, it looks at how this approach would work for rebuilding the Cannon Beach City Hall as a TEB. Geotechnical, structural and hydraulic designs and technical issues are considered in the project. The paper gives the outline for a future feasibility study that would include subsurface exploration, tsunami evacuation modeling, development of the conceptual design to allow for preliminary structure design, development of tsunami wave dissipation strategies, and assessment of costs. The goal of the future study is to test the feasibility of a TEB in a real situation which will allow communities to understand the technical and cost implications.

Keywords: evacuation building, tsunami, Cascadia subduction zone, tsunami resistant structure

\section{Introduction}

Low lying coastal communities along the Pacific Northwest are at-risk of a tsunami inundation generated by Cascadia Subduction Zone (CSZ) earthquakes. These communities were developed long before scientists understood the existing tsunami hazards. As such, about 100,000 people are in the tsunami inundation hazard zone each day in Oregon. Some of these 100,000 people are in the high hazard portion of the inundation zone nearest to ocean
Este artículo discute sobre la necesidad de un edificio de evacuación para tsunamis como un nuevo proyecto de manejo de riesgo contra tsunamis y terremotos de Cascadia. Basándose en el documento de FEMA P646 (2008), guía para el diseño de estructuras de evacuación para tsunamis, este artículo presenta este posible proyecto de reconstrucción del edificio de la Municipalidad de Cannon Beach como un edificio de evacuación para tsunamis. Se consideran en el proyecto aspectos técnicos $y$ de diseño geotécnico, estructural e hidráulico. Se entrega una descripción para un estudio futuro de factibilidad que incluiría exploración del subsuelo, modelación de la evacuación ante un tsunami, desarrollo del diseño conceptual que permita un diseño estructural preliminar, desarrollo de estrategias de disipación de olas del tsunami y evaluación de costos. El objetivo de este estudio futuro es probar la factibilidad de un edificio de evacuación para tsunamis en un caso real, lo cual permita a la población entender las implicancias técnicas y económicas.

Palabras clave: edificio de evacuación, tsunami, zona de subducción Cascadia, estructura resistente a tsunamis and river channels with long travel distances to safe and higher elevation land. In addition, many of these communities attract tourists who come to visit the ocean beaches, which are high risk areas. Coastal communities have been responding to the tsunami risk by developing emergency operation plans that include establishing evacuation routes and areas, and educational outreach programs. 
a)
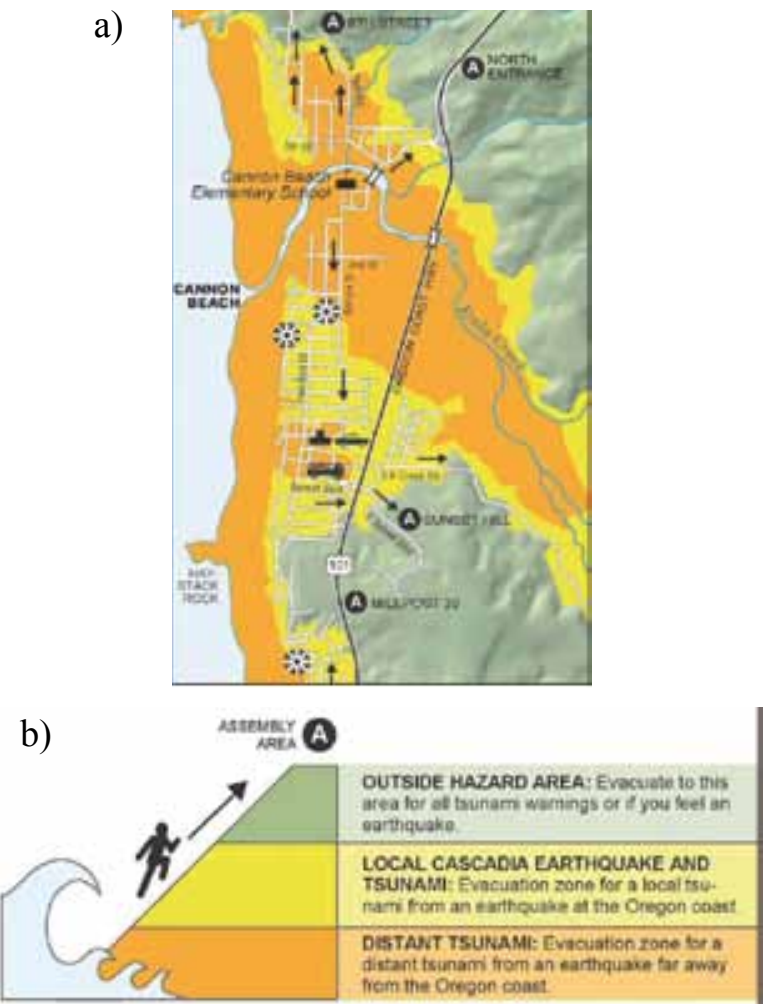

c)

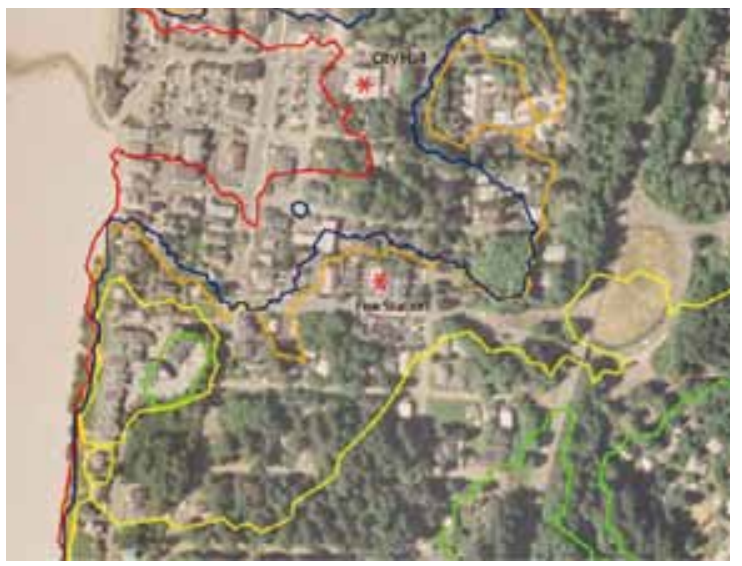

Figure 1: a) Portion of Cannon Beach tsunami evacuation map, b) index and c) inundation confidence levels from the Cannon Beach Inundation Mapping Study (DOGAMI 2008)

New tsunami inundation maps are needed for Cannon Beach, Oregon (CB). Using improved scientific data and methods (e.g. Sumatra 2004, Chile 2010, Japan 2011), new tsunami hazard maps can change risk hazards from Cascadia generated tsunamis than previous maps. The 2008 CB evacuation map shows much of the downtown, the elementary school, fire station, police station and City Hall at risk from distant and local tsunamis (Figures 1a, 1b and 1c). In addition, vulnerability studies have shown that certain populations such as visitors and elderly are also particularly at risk. It should also be noted that people will be disoriented from the earthquake and that evacuation times before the tsunami arrive range from 10 to 30 minutes for Cascadia events. An increased tsunami risk means that Cannon Beach and other coastal communities can no longer rely solely on the strategy of evacuation to higher ground but must look at tsunami evacuation buildings, structures and berms.

Tsunami Evacuation Buildings (TEBs) can be an important element to insuring that schools, essential facilities, and government buildings are able to meet their everyday purposes, and continue to function after the earthquake and tsunami. While this approach has not been done in the United States, it has been done in Japan (see Figure 2a).
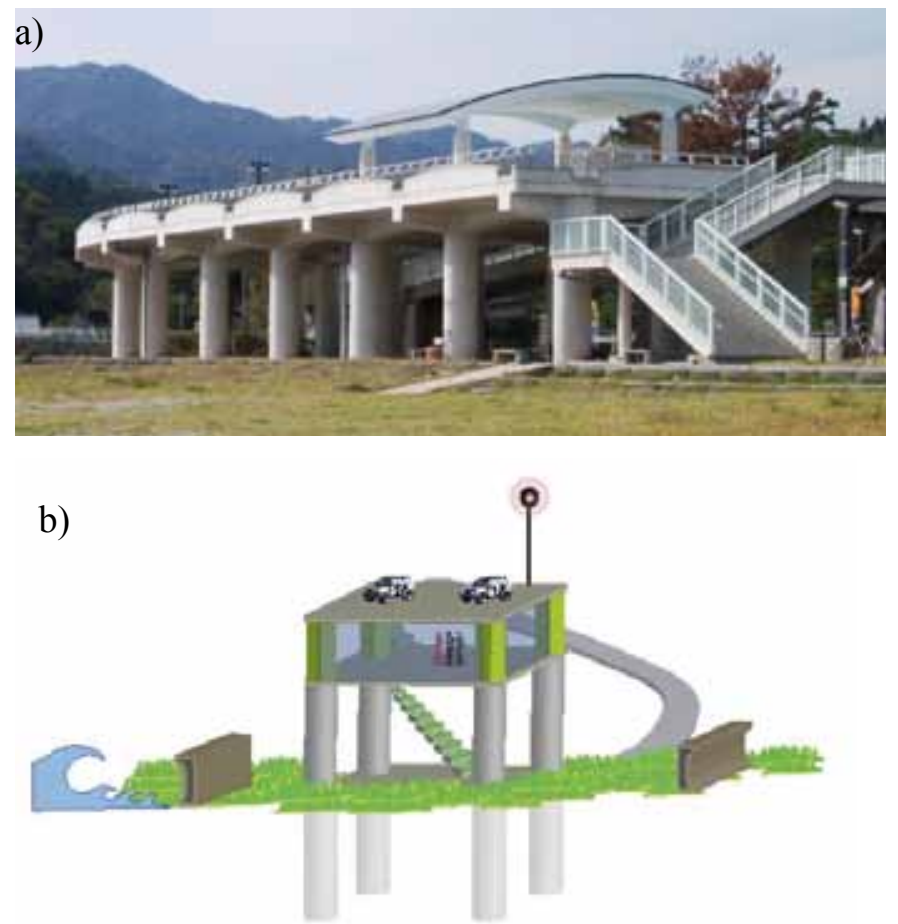

Figure 2: a) Shirahama Tsunami Evacuation Structure. Photo by Professor Nobuo Shuto and b) schematic design of a Tsunami Evacuation Building (TEB)

People who cannot safely evacuate the tsunami inundation zone should be able to evacuate to a TEB. An estimated dozen or more TEBs should be available in Oregon alone. TEBs must be able to withstand prolonged strong shaking and should be reinforced concrete structures with deep scour-resistant foundations and a minimum of two stories (Figure 2b). The lowest story should be open space on the ground floor to allow for water and debris passage. Or, the lowest floor should be designed to be sacrificial, such as with break away walls. The elevation of the bottom of the second story should be higher than the anticipated tsunami inundation elevation. The roof may be designed for general purposes, such as for parking or recreation space. It may also be designed for emergency 
purposes, such as for evacuees, heliport, emergency storage of food or medical supplies, emergency generator, emergency vehicles and so on. TEBs may be designed with energy dissipation or deflection structures facing the ocean to allow water to flow past the structure. In addition, TEB design should accommodate rapid ingress by foot traffic during tsunamis and be readily identifiable to evacuees. Accommodation must also be made for wheelchair access. TEBs should allow for a minimum of $0.5 \mathrm{~m}^{2}$ per evacuee. Because tsunamis are rare, TEBs should serve a daily purpose.

The existing Cannon Beach City Hall is expected to be critically damaged during a local and distant tsunami. Replacing the City Hall with a TEB would allow the community to accommodate evacuation needs and rely on its continued function. A new Cannon Beach City Hall TEB would serve as a demonstration project for other coastal communities with high tsunami risks.

In order to better understand elements needed to do a City Hall/TEB an ad hoc design committee was formed. The members of the committee include engineers, an architect, and scientists who do dynamic evacuation modeling. This paper presents and describes a TEB conceptual design which identifies issues to be addressed.

\section{Cannon Beach, a tsunami ready community}

Cannon Beach is a small community located on the northern Oregon coast eighty miles west of Portland. The city has a full time resident population of 1,690 residents that is augmented by around 3,000 part time residents. Tourists visiting the city can range from several thousands to tens of thousands on any given day. Economic activity is centered on tourism. The city has high risk factors for tsunamis because a majority of the population and economic activity is located in the tsunami inundation zones and has many visitors who also tend to gather in the tsunami inundation zones. In addition, the population has a fairly high percentage of retirees.

Cannon Beach, a Tsuanmi Ready community, has been active in preparing for the Cascadia subduction zone earthquake and tsunami as well as distant tsunami. Starting in the 1990's the Cannon Beach Rural Fire District installed a series of siren/loudspeakers to warn visitors of approaching distant tsunamis and started tsunami education efforts. The city of Cannon Beach joined in these efforts by establishing the Emergency Preparedness Committee which developed an Emergency Operations Plan, identified evacuation routes and areas, created on-going community outreach and education programs, established shelter sites (along with seismic evaluations of the shelters), as well as other recommendations to the city to strengthen emergency response. The Fire Station was relocated to high ground and contains the Emergency Operations Center (EOC) for the community.

Cannon Beach then turned its attention to relief and long term disaster recovery. It was aided in this effort by a workshop funded by the Cascadia Earthquake Emergency Workgroup, in which Oregon Natural Hazards Workgroup, Oregon Emergency Management and USGS that brought community leaders, the school district, utility companies, health care providers, and the business community together. Out of this workshop, the city created the "Prepare for Emergency Recovery Committee" (PERC), a staff committee focused on relief and immediate post disaster recovery efforts, and the Long Term Disaster Recovery Committee, which is an advisory committee looking at developing pre-disaster mitigation strategies.

\section{New City Hall/TEB}

The decision to look into rebuilding the existing City Hall as a TEB was due to the lack of availability of an alternate site above the inundation zone and to the fact that it was well situated to provide refuge to residents and visitors in the downtown and midtown areas, both highly populated and vulnerable areas. It is also very visible from a major beach access.

The existing building is $810 \mathrm{~m}^{2}$ and if replaced is large enough to provide refuge to at least $800-1,000$ people on the second level and possible roof terrace.

Figure 3 shows the developed conceptual design which incorporates the primary elements of a TEB. The building was raised on columns to allow water pass beneath the structure. The second floor level was set to be above not only the most likely tsunami event, but most of the rare tsunami events as well. A roof terrace was provided for additional refuge area and for high inundation depths. Exterior stairs were placed as a 
very visible design feature to make the building readily identifiable as a tsunami refuge. The lower level is open to provide parking. The building also was designed to serve other functions so that the lower level can shelter the Farmers Market and the roof terrace is a public open space where Haystack Rock is visible. Accessibility is being planned for with the use of elevators designed to be functional after the earthquake. Emergency power and supplies will also be included. Strategies for wave dissipation can be provided for in the parking lot in front of City Hall.

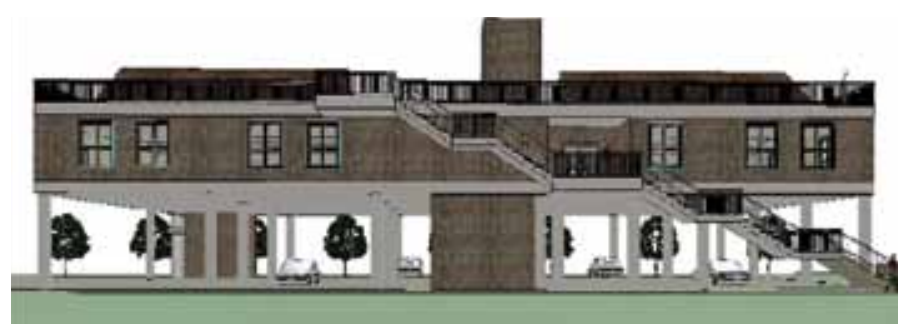

Figure 3: Cannon Beach City Hall/TEB conceptual design by Ecola Architects (2008)

The conceptual design must meet the city's zoning ordinances. These ordinances included providing off street parking, setting the building back from the residential zone south by $6 \mathrm{~m}$, providing landscaping, and a building height limit of $8.5 \mathrm{~m}$. The conceptual design showed that all zoning ordinances can be met except for the $8.5 \mathrm{~m}$ height limit. This would require a variance from the City, but it is considered an acceptable request given the nature of the project. The city also has as Design Review requirement so that the aesthetics of the building must be acceptable to the community.

Disabled accessibility is a requirement for public buildings. The most straightforward solution is providing at least one elevator to the building, built to a high seismic resistance standard and provided with emergency power to insure function after the earthquake. The option of an accessible ramp was examined and it was determined that not enough space was available for the length of ramp required, especially if the ramp had to reach to the roof terrace as well. Therefore, large ample stairs were provided on the exterior of the building.

The building has to be readily identifiable as a refuge for a tsunami. The conceptual design solution was to make the stairs to the upper level and to the roof terrace a very distance and visible part of the design. The stairs were placed on the south side of the building and made very visible to people evacuating along Hemlock street, the main street in town. The city of Cannon Beach has design review guidelines for commercial and public buildings. An initial attempt to meet these guidelines included to have a gable roof over part of the roof and using cedar shingles, which are a common siding material in town. One design element that needs further study is creating an attractive ground story. This level will need to be used for parking in order to meet the zoning ordinances for off street parking. However, possible secondary uses of the covered area include a new Cannon Beach Farmer's market which may provide additional design parameters to create a pleasing space under the building.

Relocating the City Hall had been considered as an alternative when its vulnerability was first realized. This thinking changed when it became evident that there was not suitable available land within the city limits, or in close proximity. The existing location was good for its proximity to the citizens and providing them services. Relocating the City Hall would have required mitigating effects on the daily lives of the citizens.

\section{Tsunami seawall for Cannon Beach City Hall}

Seawalls, bulkheads and revetments are coastal structures that are used to protect shoreline land from erosion due to rising sea levels and waves. The shoreline structures are constructed of structural soil fill, geotextile fabric, large stones, steel, reinforced concrete or some combination of these materials. The optimal structure type is determined by the predicted water levels, wave climate, material availability and soil classifications.

Shoreline placed seawalls may have significant short and long term environmental impacts. Short term water quality can be decreased from construction activity. Long term sand circulation and displacement can affect habitat for marine life. Seawalls may limit beach access and may be intrusive on the shoreline views. Reinforced concrete seawalls can withstand higher wave forces than soil revetments and stone bulkheads. They are designed to absorb breaking wave energy or reflect waves seaward or upward. 
When tsunamis propagate inland, wave fronts can take the shape of either a bore or surge. These destructive waves can carry debris, such as logs, creating high impact loads and cause extensive damage to wooden and unreinforced masonry structures. To dissipate some of this tsunami energy, the Canon Beach City Hall TEB will have two reinforced concrete seawalls along the west and east sides of the buildings.

The primary objective of the tsunami seawalls is to dissipate some of the tsunami energy and debris forces by wave front upward deflection and debris damming. The more wave and debris energy that can be absorbed or dissipated by the wall prior to reaching the building, the less robust the building will need to be. The seawall is not intended to completely prevent tsunami inundation of the City Hall, but merely to dissipate some of the tsunami energy.

More investigation is required to determine the exact location of the tsunami seawall relative to the Canon Beach City Hall. An estimate of the tsunami seawall location is near the building and approximately $200 \mathrm{~m}$ from shore. No environmental impacts are anticipated at this time and the wall is not expected to limit beach access.

\section{Tsunami seawall design considerations}

The City Hall will have two pile supported reinforced concrete walls. The ocean side west wall is rendered in Figure 4 and the landward east wall is rendered in Figure 5. Both of these figures are conceptual and are modified figures from the Shore Protection Manual (1984). The west wall is a combination of stepped and curved face and the east wall is a curved faced only. The curved face of the wall reflects the wave energy upward, causing the tsunami to dissipate some of its destructive energy before reaching the building. The wall absorbs impacts and damming debris forces. The west wall dissipates wave energy from the run-up and the east wall dissipates wave energy from the drawdown. The rip rap resists scour from the run-up and drawdown. Greater scouring has been observed to occur during drawdown. The seawalls are constructed of steel reinforced concrete. The west wall would be best located in the parking lot where a natural grade difference already exists. To build and design an effective and efficient tsunami seawall for Cannon Beach, more information is needed about the expected tsunami wave and the soil types below the walls. The design tsunami wave shape, velocity, height and frequency govern the forces needed to design seawalls. Soil mechanics studies are needed to determine pile depths and width of wall.

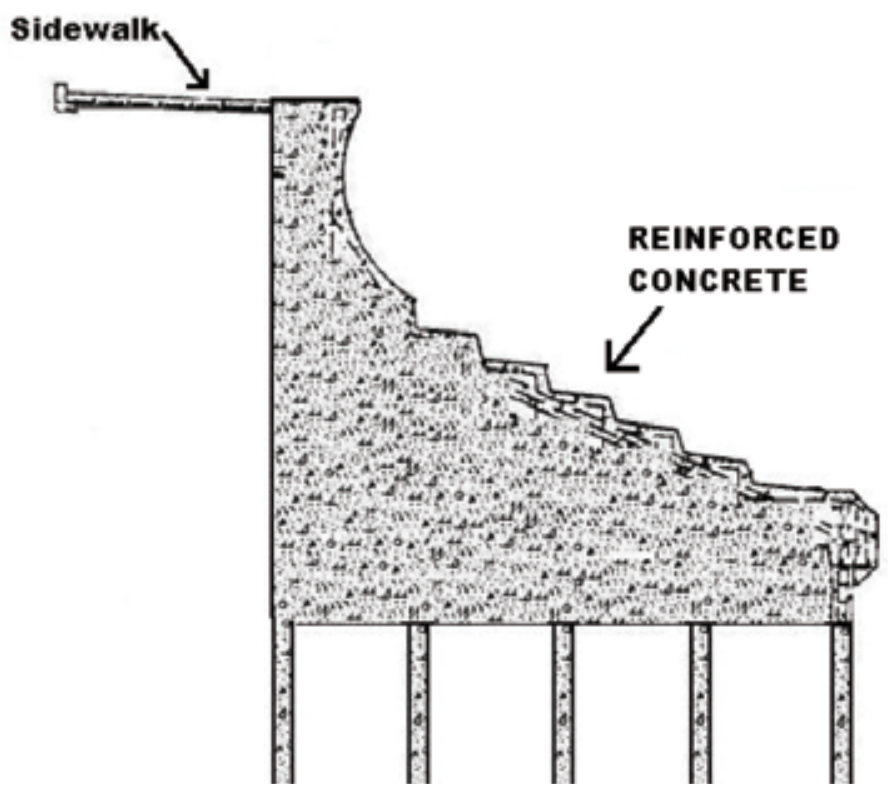

Figure 4: Combination stepped and curved face pile support seawall, modified from Figure 6-2, Shore Protection Manual (1984)

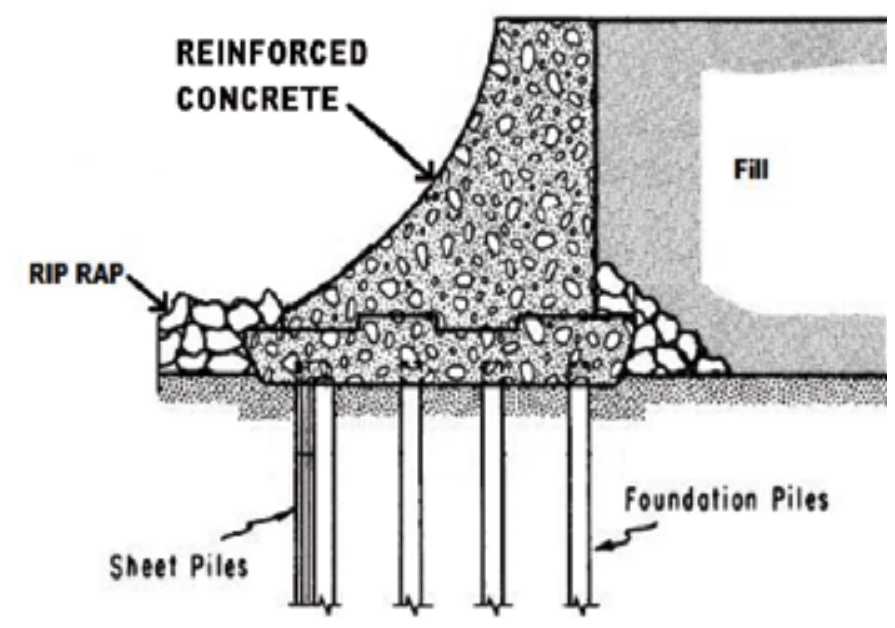

Figure 5: Pile supported and reinforced concrete curved face seawall, modified from Figure 6-1 Shore Protection Manual (1984), proposed east City Hall tsunami wall.

\section{Cannon Beach City Hall structural design considerations}

Cannon Beach is located on the seismically active Oregon coast. It is likely affected by tsunamis and strong seismic shaking generated by a Cascadia subduction earthquake. In order to function as a refuge from tsunami, the proposed Cannon Beach City Hall/TEB must remain usable 
following a major seismic event. This, in turn, requires the building to retain most of its pre-earthquake lateral-force resistance, experience little nonstructural damage, and be capable of resisting expected tsunami loading effects.

\section{Seismic performance objective}

There is limited guidance available to explicitly address required seismic performance of a TEB structure. FEMA P646 (2008) recommends that such structure be designed to meet Immediate Occupancy performance (as defined in ASCE/SEI 41-06) for the Design Basis Earthquake (DBE) and Life Safety performance for the Maximum Considered Earthquake (MCE). However, we feel that this recommended performance requirement could not guarantee the usability for a tsunami if the building experiences significant structural damage at the MCE level, with inadequate lateral resistance for a tsunami. A building that experiences substantial structural damage or out of plumb may be considered as Life Safe, however, it can not be re-usable without substantial repair.

To make evacuees feel comfortable entering the TEB and remaining in the structure during the aftershocks, the structure is expected to remain plumb with limited structural damage (especially near stairs and ingresses) that does not require any repair work prior to being occupied. Since a tsunami evacuation building is expected to remain functional and perhaps, be used for emergency response and/or medical care for a period of time, it is important to have higher-level performance of nonstructural components with limited damage. For the TEB, we feel that it is more appropriate to design the building to meet Immediate Occupancy performance level for the MCE event. As part of the design process, it is essential to perform verification analyses to ensure the performance objective is met using available performance-based earthquake engineering techniques such as ASCE/SEI 41-06.

\section{Structural system and seismic design consideration}

There are several structural systems founded on deep piles that can achieve the required seismic performance and allow tsunami debris to flow through at the lower levels and keep the hydrodynamic loads to a minimum: steel frames with dampers, post-tensioned reinforced concrete frames (Figure 6a), and posttensioned concrete shear walls (Figure 6b). The posttensioned reinforced concrete frames and post-tensioned concrete shear walls rely on the post-tensioning tendons to re-center the structure to its pre-earthquake position. When properly designed, the building with these systems tends to have limited residual displacement even for the MCE event. Since the steel structure is more prone to corrode in the coastal environment, post-tensioned concrete frames or a combination of concrete frames with concrete shear walls parallel to the direction of anticipated tsunami flow are more suitable for the TEB, and also compatible with the planned function at the ground level of either parking or farmer's market.

a)

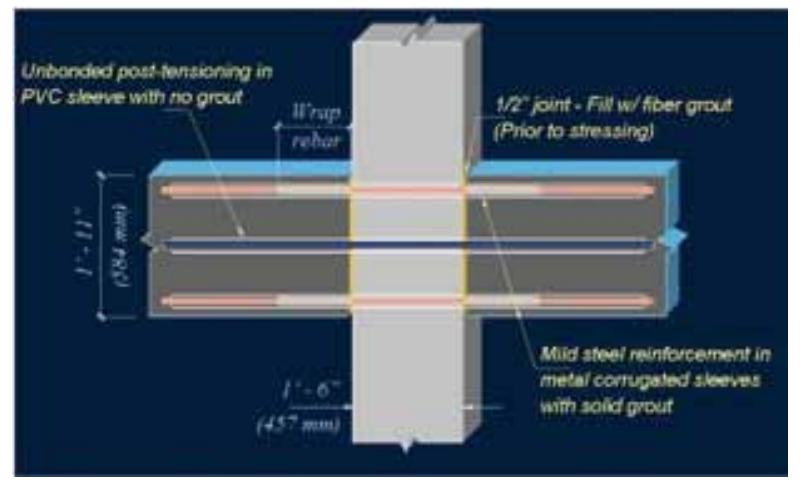

b)

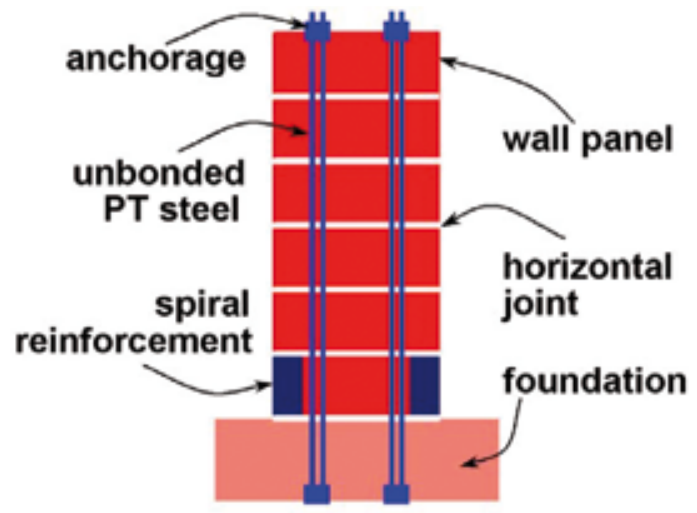

Figure 6: Lateral-force resistance systems: a) post-tensioning hybrid concrete frame (Sritharan et al. 2000) and b) posttensioning concrete shear wall (Restrepo and Rahman 2007; Schoettler et al. 2009)

Figure 7 shows a conceptual layout of lateral force resistance system for the Cannon Beach TEB. It is expected that the site would likely experience liquefaction during the seismic shaking, which could result in differential settlement of ground soil. Also, significant scouring due to tsunami is likely to occur at the site. To minimize the undesirable effects of liquefaction induced differential settlement and scouring on the structural system, piled foundation is recommended as shown in Figure 8 to support 
the columns of both seismic and gravity frames. Pile caps are interconnected with grade beams and ground slab to ensure lateral forces can be distributed to all the piles.

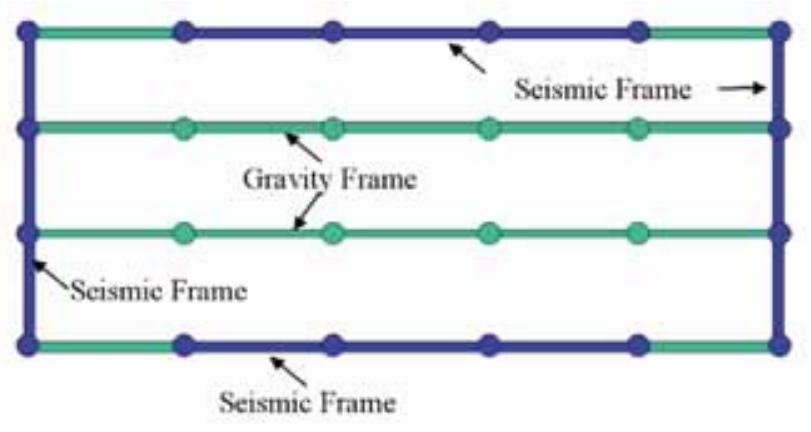

Figure 7: TEB seismic system layout: plan view

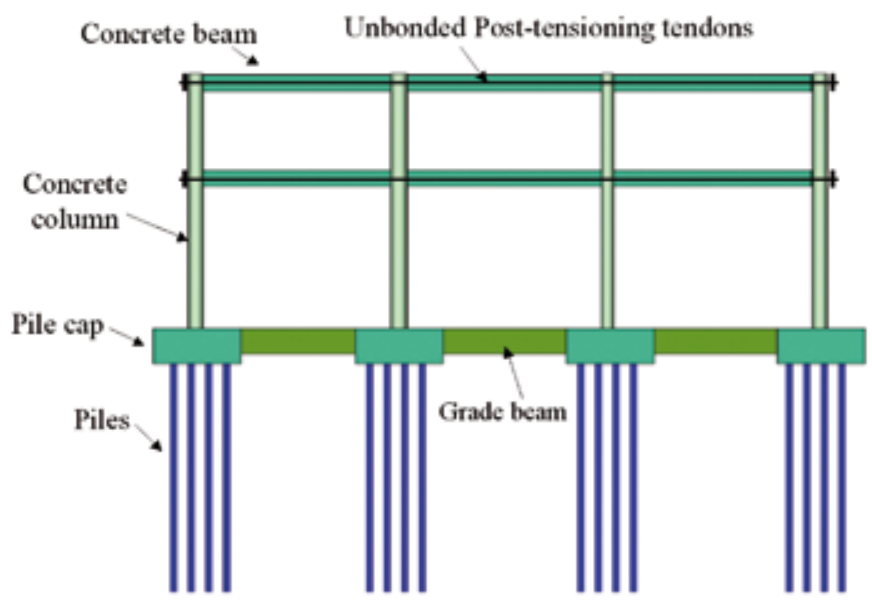

Figure 8: Typical post-tensioning concrete frame elevation

\section{Tsunami-resistant design consideration}

The concrete columns in the lower level are designed with circular cross-sections to minimize hydrodynamic loads and impact loads associated with waterborne debris. At the City Hall site, the tsunami inundation depth is estimated to range from $1.8 \mathrm{~m}$ at the most likely tsunami to $4.5 \mathrm{~m}$ to $9 \mathrm{~m}$ in rare events. Both the second level and a roof terrace are planned for refuge. Given the uncertainty involved in the tsunami modeling and estimate, if the first story height is set unconservatively low, the run-up water could potentially exceed the first story height, wash away the contents in the second story, and pose buoyancy and hydrodynamic uplift force on the $2^{\text {nd }}$ floor concrete slab. Thus, the design must consider carefully the story height for the first story.

The concrete floor framing and slab at the $2^{\text {nd }}$ and the roof levels are designed to accommodate refuge live load. The slab to beam connection at the ground and the $2^{\text {nd }}$ floor levels need to be strong enough to resist any potential buoyancy and hydrodynamic uplift forces on the slab.

In case that wood stud walls are used in the building, detailed connections with a fuse at the top and sides are needed to minimize the hydrodynamic loads on the building structure (Yeh 2007). Due to uncertainties involved in the estimate of impact forces associated with waterborne debris, the TEB design should incorporate considerations of the "tie force" strategy and the "miss column" strategy in the design to reduce the potential for progressive collapse if one column is severely damaged (FEMA P646 2008).

After a major seismic and tsunami event, the City Hall is expected to function for relief and post disaster recovery. It is important to ensure that the nonstructural systems including ceiling, communication system, fire suppression system, distribution lines and tall furnishings are properly braced to reduce the falling hazards and reduce the potential for loss of function. Seismic design shall follow the recommendations contained in ASCE 41-06.

\section{Geotechnical and scour considerations}

Deep concrete foundations should be selected for the TEB instead of shallow foundations such as mat foundations, because of the scour potential that can occur during a tsunami. Concrete structures better survived the tsunami inundation as observed in the 2004 Sumatra tsunami.

A local Cascadia Subduction Zone (CSZ) earthquake (up to $M_{w}=9$ ) would create high lateral soil forces on the foundations and residual liquefaction of the underlying saturated loose to medium dense sandy/silty soils. Foundation should be designed to withstand the earthquake forces and the dynamic total and differential settlement.

Residual liquefaction occurs when saturated deposits of loose to medium dense, cohesionless sands and silts, are subjected to strong earthquake shaking. If these saturated deposits cannot drain rapidly, there will be an increase in pore water pressure. With increasing oscillation, the pore water pressure can increase to the value of the overburden pressure. Theshearstrength of a cohesionless soil is directly proportional to the effective stress, which is equal to the difference between the overburden pressure and the pore 
water pressure. Therefore, when the pore water pressure increases to the value of the overburden pressure, the shear strength of the soil reduces to that of a liquid (zero), and the soil deposits turn to a liquefied state. Deep foundations would need to extend below the depth of the liquefied soil. Soils subject to residual liquefaction should be neglected for their contribution to skin friction and lateral support.

Other earthquake geotechnical hazards include severe ground shaking, lateral spreading and rapid coastal subsidence. Lateral spreading is the downward horizontal movement of soil toward a slope that occurs over or within seismically liquefied soil. Coastal subsidence is defined as a large scale downward movement of the earth's surface. Coastal uplift can also occur in the form of significant upward movement.

The TEB could be affected by tsunamis from two sources, but the effect on the foundation would be similar. One tsunami source would be one that occurs because of the local CSZ earthquake. In this case, the ground shaking and potential tsunami could occur within minutes of each other. The second source would be a distant earthquake that occurs far away from the Oregon Coast without any local earthquake effects. Scour would occur for both tsunamis. The support for mat foundations could be eroded during either tsunami event. Deep concrete foundations could extend below the anticipated scour depth and would be the most appropriate building support method.

Tsunami scour depth is difficult to predict because of the many variables that govern the scour mechanism. The key governing parameters are flow velocity, the number of piles, the shape, alignment and size of the piles and properties of the soil around the pile. Other factors include the depth of the surge, the proximity to the shoreline and wave breaking height. Current codes (ASCE 7-05) give consideration to scour, but do not provide guidance for calculating the depth of scour.

Localized tsunami scour can be calculated as a percentage of still water depth (wave height) relative to soil type and proximity to the shoreline (FEMA 55, 2000). Floodwater velocity strongly affects scour depths as summarized in the EERI/FEMA NEHERP (2006) document.
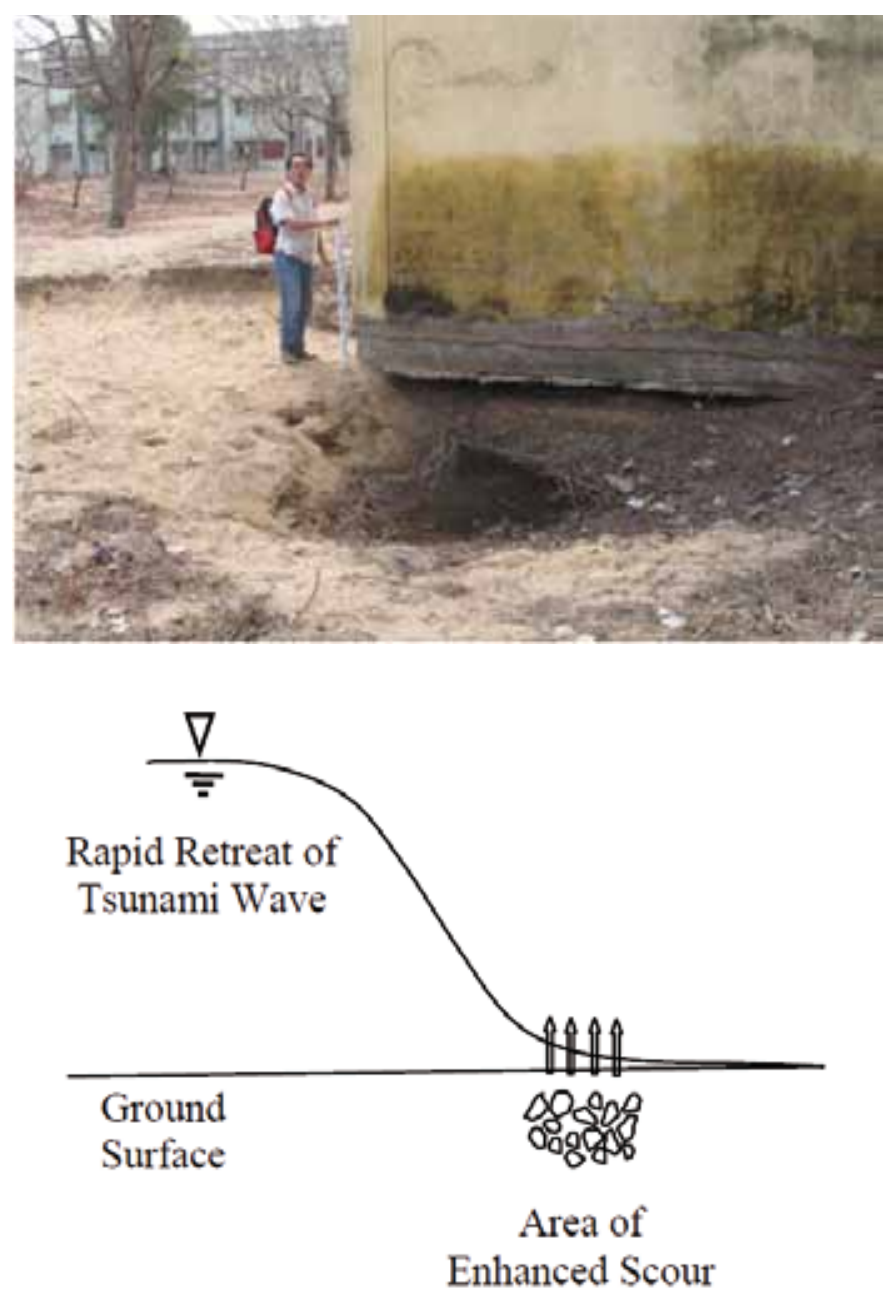

Figure 9: Tsunami scour, a) tsunami run-up height of $4.1 \mathrm{~m}$, inundation depth of $0.95 \mathrm{~m}$ above the floor and scour depth of $1.2 \mathrm{~m}$ (photo provided by Harry Yeh) and b) enhanced scour

Momentary liquefaction (enhanced scour) occurs at the ground surface because the saturated soil is easily transported as a liquid (Figures 9a and 9b). Enhanced scour can occur at the end of wave drawdown (wave retreat). During and after wave drawdown, the pore water pressures in the near surface soil increase and momentary liquefaction can occur. Momentary liquefaction occurs with the rapid reduction in total vertical stress (loss of wave height) in a soil saturated by water inundation. The shear strength of the saturated soil reduces to zero and the soil behaves like a liquid. The difference between residual liquefaction and momentary liquefaction is that residual liquefaction occurs below the water table.

Scour can be reduced by placing gravel and/or rip 
rap around piles. This reduction in scour occurs because gravel/rip rap is more permeable than sand, making the change in pore water head less dramatic.

Subsurface conditions on the site of the existing Cannon Beach City Hall are not specifically known. However, reports from nearby sites show variable layers of subsurface soils. The subsurface soils generally consist of fill underlain by layers of silt with varying amounts of clay and organics, gravel and sand. The layering is generally not similar between borings. Perched groundwater could be present at depths as shallow as 1.8 $\mathrm{m}$. Static groundwater can be present at depths as shallow as $4 \mathrm{~m}$ based on nearby well logs, although it has been encountered at depths as deep as $9 \mathrm{~m}$.

The proposed location of the TEB is likely in or near a preexisting drainage. The highly variable subsurface conditions observed in the vicinity are typical of coastal lagoon, fluvial and shoreline alluvial deposits. Therefore, it is difficult to extrapolate the actual subsurface conditions due to rapid lateral and vertical subsurface changes. Current thought is that the fill under the TEB location may be thicker than adjacent sites because of the possible presence of a preexisting drainage. The depth of the fill will be unknown until borings can be advanced at the proposed building location. Regardless of the thickness of fill at the site, deep foundations are necessary for the TEB that is proposed for Cannon Beach because of the potential for local CSZ earthquakes. The foundations would need to extend into firm material below anticipated seismic liquefaction and/or scour depths. The firm material at the site could consist of beach sand, dune sand or quaternary marine terrace deposits that are mapped in the area.

\section{Development of a tsunami simulator for Cannon Beach}

It is impractical to give warning and evacuate people from the direct effects of an earthquake, since the fault rupture and ground motion occur almost concurrently. In contrast, the lead-time between detection of a seismic signal and the resulting tsunami make warning and evacuation possible. For a local tsunami triggered by the Cascadia earthquake, the tsunami will arrive at the shore of Cannon Beach within 30 minutes. Note that for a mega event like
$M_{w}=9$, ground shaking could last more than 5 minutes. Hence, effective time used for evacuation would be very limited and evacuation to the natural high ground may not be an option. Therefore, providing a tsunami shelter at a strategic location can be a viable means to save lives.

Proposed herein is the development of an integrated simulator to evaluate the effectiveness of building a tsunami shelter into the Cannon Beach City Hall. The simulator combines three models simulating the hydrodynamics of tsunami propagation and inundation, then dissemination of warning information, and human response to the warnings. The simulations are integrated and presented in a GIS (Geographic Information System) framework using realistic computer graphics. In addition to evaluating the effectiveness of a tsunami shelter, this simulatorwill be used as a tool for the City of Cannon Beach to improve both warning systems and evacuation tactics. The visual GIS presentation also makes the simulator ideal for educating the general public, including visitors, on the consequences of how they respond to tsunami warnings.

\section{Simulation of tsunami scenarios}

Acomprehensive scenario simulator has been developed to support rational tsunami hazard and vulnerability analyses. The simulator integrates three modules: 1) hydrodynamic numerical simulation of tsunami propagation and run-up, 2) warning transmission simulation, and 3) evacuation simulation. Although the hydrodynamic simulation is deterministic, the other two components are probabilistic. Hydrodynamic simulation models for tsunami generation, propagation, and run-up have been used often in practice (e.g. Titov and Synolakis, 1998; Lin et al., 1999; Imamura, 1996). While the numerical algorithm itself is considered adequately accurate (e.g. Yeh et al. 1996), it remains difficult to determine practical tsunami-source conditions. Fortunately, Oregon has just completed a thorough investigation to estimate the most credible tsunami source for the Cascadia events; the study is an extension of a previous study (Priest et al., 1997) coupled with geological paleo-tsunami deposit data (Witter et al., 2008). Furthermore, Zhang and Baptista (2008) have conducted detailed numerical simulations specifically for the inundation in Cannon Beach.

The warning transmission module models both official 
("broadcast") and informal ("contagion") processes. The informal network (person-to-person oral communications) is the primary method of warning transmission, since official warnings (processed by government authorities and transmitted by loudspeakers, route alert vehicles, radio, and TV) are relatively slow in responding to a locally generated tsunami and might be totally destroyed by the earthquake causing the tsunami. In the model, informal communications are controlled by four parameters: 1) the number of households, 2) the distances among households, 3) the delay in initiating contact, and 4) preference parameters. Our model includes preferential contacts based on a probabilistic biased network model (e.g. Rapoport, 1979; Fararo,1981; Skvoretz, 1985). In addition, there are control parameters distinguishing "normal" days from those with stressed conditions during disasters. For example, the number of contacts (receivers) is larger during disasters, the communication distances between contacts are shorter, and the preference parameter is weaker. A majority of control parameters must be determined based on demographic data. Fortunately, thorough collections of such data are available for Cannon Beach (Wood, 2007). Additional parameters control the loudspeaker warning system (loudspeaker locations, audible distances, audience share, announcement frequency, and timing), route alert vehicles such as police cars and fire engines (routes and speeds, dispatch timing, audible distance, and audience share), and radio/television (audience share, announcement frequency, and timing). Evacuation simulationismodeled in twosteps: 1)individuals'decisionmaking and preparation processes for evacuation, and 2) the actual evacuation process. The first step reflects:

-the number of repeated warnings received (and from which channels)

-evacuation actions taken by neighbors and friends

-location of the household

-prior knowledge and/or experience of tsunamis

-time to evacuate after the decision is made

Those parameters are assigned based on Wood (2007). The current model only simulates the evacuation of individuals moving on foot toward the closest shelters or high ground, but evacuation methods (e.g. motor vehicles) and potential setbacks (road blockage, bridge failure, etc.) can be introduced.
The integrated simulator uses a GIS framework to produce an animation of the tsunami run-up (typically occurring in multiple waves), warning transmission patterns, and individuals' protective responses. Figure 10 shows how the components interact. To evaluate the overall outcome, the program determines 1) the number and spatial distribution of households receiving a warning, 2) the temporal distribution of those warnings, 3) the cumulative effects of informal communication (oral and telephone) patterns, and 4) number of casualties. Once an area is inundated by a tsunami, a newly developed casualty model is applied to determine fatalities. The casualty model is based on whether a person can remain standing within the tsunami flow and incorporates age and gender differences (Yeh, 2010). Figure 11 shows an example of the animated display for the scenario simulator.

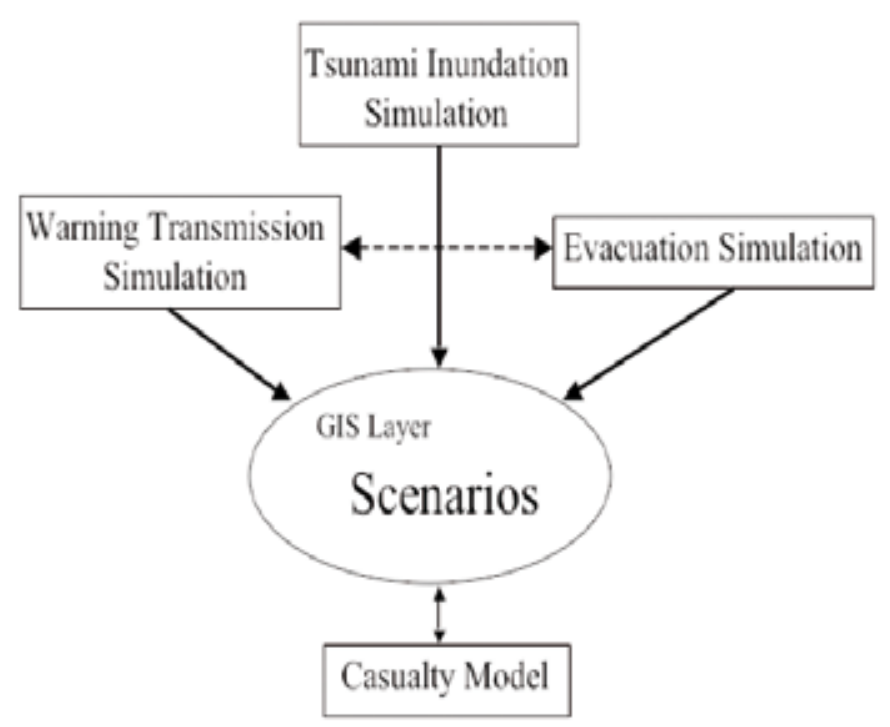

Figure 10: Schematic representation of the integrated tsunami scenario simulator

The proposed development of the tsunami scenario simulator does not only provide quantitative evaluations for the effectiveness of the Cannon Beach tsunami shelter, but is also useful in identifying the effects of hazard mitigation measures (such as seawalls), emergency response resources (e.g. number and capacity of evacuation routes, locations of tsunami shelters) and emergency response procedures (e.g. amount of forewarning and routing of route alert vehicles). 

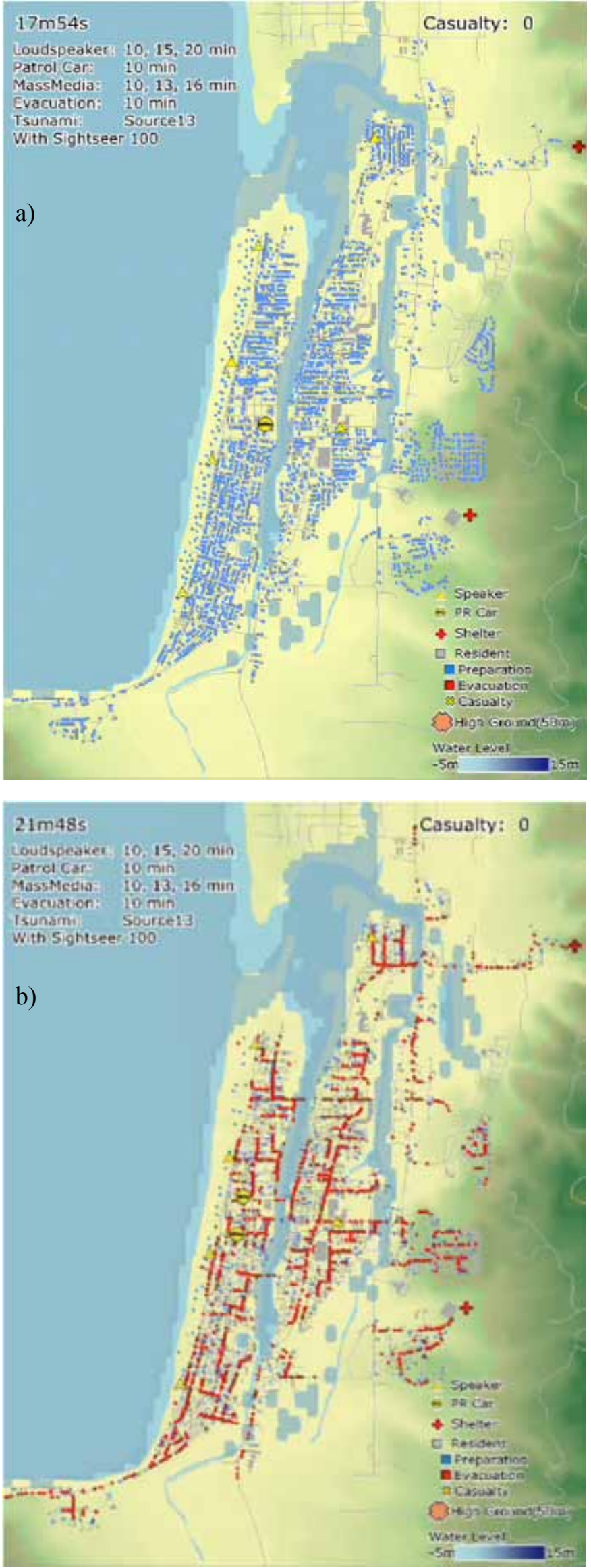

Figure 11: An example of animated tsunami scenario simulation. Note that the casualty numbers are shown in the upper right corner, a) 18 minutes, b) 22 minutes

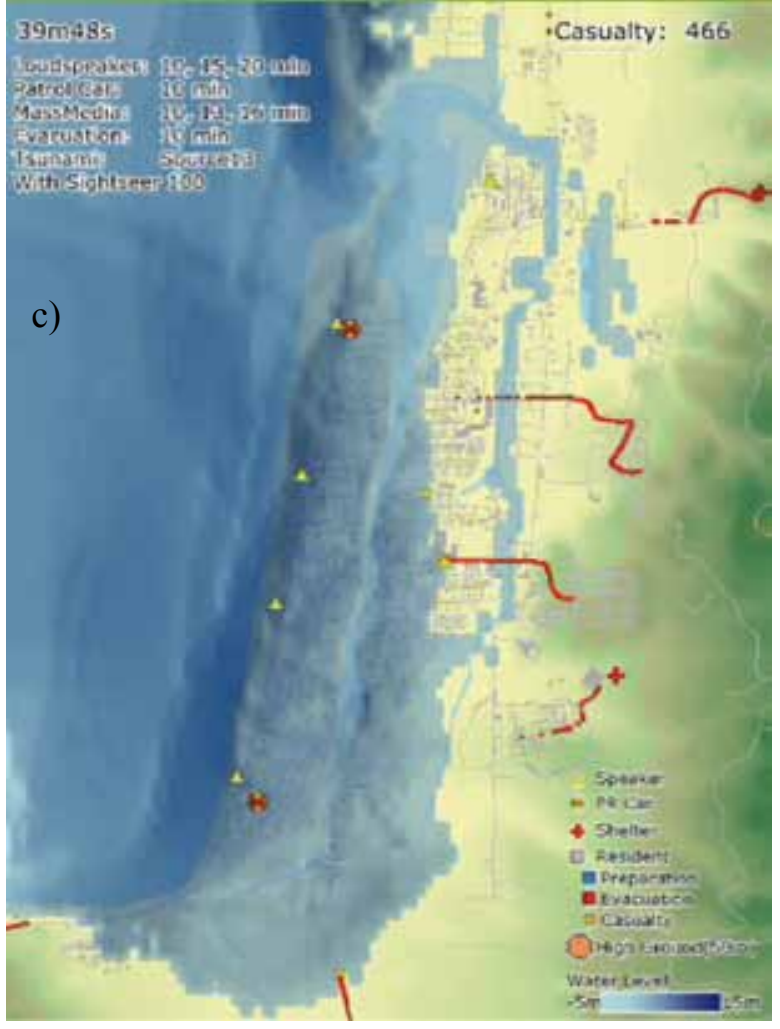

Figure 11: Continuation, c) 40 minutes

\section{Summary and next steps}

The design concepts discussed in this paper set the stage for future design and construction of the proposed Cannon Beach City Hall TEB. It provides the basis for future action including subsurface exploration, tsunami evacuation modeling, additional development of the conceptual design to allow for structural design and tsunami wave dissipation design, and construction. The goal is to construct a Cannon Beach City Hall TEB by March 2014, which is the 50 year anniversary of the 1964 Great Alaska earthquake, which triggered a tsunami that damaged portions of Cannon Beach. The preliminary cost estimate to construct a $900 \mathrm{~m}^{2}$, two-story building with a roof terrace on deep foundations is on the order of US\$4 millions. The purpose of the building is to save lives in Cannon Beach, augment local emergency response efforts, and allow for long term recovery for Cannon Beach and nearby communities. The broader goal is to be a demonstration project to help increase tsunami preparedness for all tsunami prone communities. This demonstration project would provide information for other coastal communities to better understand the many technical, social, design, and cost implications. This in turn, will allow coastal communities to develop appropriate and comprehensive tsunami evacuation and mitigation strategies. 
Many coastal communities in the Pacific Northwest and elsewhere in the world, such as Chile, countries around the Indian Ocean and Pacific Rim, have a high tsunami risk and will have tsunami damage. Building TEBs are an emerging mitigation strategy that can be considered.

\section{Acknowledgments}

The authors are grateful to the many supporters of the proposed Cannon Beach TEB, including individuals from FEMA, NOAA, the Council on Disaster Risk Management of the American Society of Civil Engineers, DOGAMI, Oregon State University and the leaders from Cannon Beach. We dedicate our work to honor the people who have suffered in past tsunamis.

\section{References}

ASCE/SEI 41-06. Seismic Rehabilitation of Existing Buildings

ASCE 7-05 Minimum Design loads for Buildings and Other Structures.

DOGAMI (2008). Prehistoric Cascadia tsunami inundation and run up at Cannon Beach. Open-File Report O-08-12, Clatsop County, Oregon, Rob Witter

Ecola Architects (2008). Cannon Beach City Hall/TEB conceptual design study.

EERI/FEMA NEHERP (2006). Tsunami inundation scour of roadways, bridges and foundations, observations and technical guidance from the Great Sumatra Andaman tsunami. Professional Fellowship Report.

Fararo, T.J. (1981). Biased networks and social structure theorems. Social Networks 2, 1-18

FEMA P646 (2008). Guidelines for design of structures for vertical evacuation from tsunamis.

FEMA 55 (2000). Principles and practices of planning, siting, designing, construction, and maintaining residential buildings in coastal areas. Coastal Construction Manual, third edition

Imamura, F. (1996). Review of tsunami simulation with a finite difference method. In Long Wave Runup Models (Yeh, Liu and Synolakis eds.), 25-42

Lin, P., Chang, K-A. and Liu, P.L-F. (1999). Runup and rundown of solitary waves on sloping beaches. Journal of Waterway, Port, Coastal and Ocean Engineering, ASCE, 125, 247-255

Priest, G.R., Baptista, A.M., Flück, P., Wang, K., Kamphaus,
R.A., and Peterson, C.D. (1997). Cascadia subduction zone tsunamis: Hazard mapping at Yaquina Bay, Oregon. Final Technical Report to the National Earthquake Hazard Reduction Program, Oregon Department of Geology and Mineral Industries Open-File Report O-97-34, 144 p.

Rapoport, A. (1979). A probabilistic approach to networks. Social Networks 2, 1-18

Restrepo, J.I. and Rahman, A. (2007). Seismic performance of self-centering structural walls incorporating energy dissipators. Journal of Structural Engineering 133, No.11, 1560-1570

Schoettler, M., Belleri, A.,Zhang, D., Restrepo, J., and Fleischman, R. (2009). Preliminary results of the shake-table testing for the development of a diaphragm seismic design methodology. PCI Journal, winter, $100-124$

Shore Protection Manual (1984). Coastal Engineering Research Center. Volume II, USACE

Skvoretz, J. (1985). Random and biased networks: simulations and approximation. Social Networks 7. 225-261

Sritharan, S., Priestley, J.J.N., Seible, F. and Igarashi, A. (2000). A five story precast concrete test building for seismic conditions - an overview. Proceedings of the Twelfth World Conference on Earthquake Engineering, Auckland, New Zealand, Paper No. 1299

Titov, V.V. and Synolakis, C.E. (1998). Numerical modeling of tidal wave runup. Journal of Waterway, Port, Coastal and Ocean Engineering, ASCE, 124(4), 157-171

Witter, R.C., Zhang, Y. and Priest, G. (2008). Reconstructing hydrodynamic flow parameters of the 1700 tsunami at Ecola Creek, Cannon Beach, Oregon. Final Technical Report, U.S. Geological Survey

Wood, N. (2007). Variations in city exposure and sensitivity to tsunami hazards in Oregon. Scientific Investigation Report 20075283 , U.S. Geological Survey, U.S. Department of the Interior, $43 \mathrm{pp}$.

Yeh, H. (2010). Gender and age factors in tsunami casualties. Natural Hazards Review 11 (1), 29-35

Yeh, S.H. (2007). Design tsunami forces on onshore structures. Journal of Disaster Research 2, No.6, 531-536

Yeh, H, Liu, P. and Synolakis, C. (1996). Long Wave Runup Models. World Scientific Publishing, Singapore.

Zhang, Y.J. and Baptista, A.M. (2008). An efficient and robust tsunami model on unstructured grids. Part I: inundation benchmarks. Pure and Applied Geophysics 165, 2229-2248 